УДК 159.98:316.362:376-058.68

DOI https://doi.org/10.32838/2709-3093/2021.4/17

Шевчук В.В.

Полтавський національний педагогічний університет імені В.Г. Короленка

\title{
ЕМОЦІЙНІ ПЕРЕЖИВАННЯ БАТЬКІВ ДІТЕЙ ІЗ КОМПЛЕКСНИМИ ПОРУШЕННЯМИ РОЗВИТКУ
}

У статті представлено результати теоретичного й емпіричного дослідження психологічних особливостей емоиійних переживань батьків, які виховують дітей із комплексними порушеннями розвитку, у порівнянні з батьками дітей без вад розвитку.

У намому емпіричному дослідженні взяло участь 152 батьків, які виховують дітей зі складними мовленнєвими вадами й розумовою відсталістю, 136 батьків дітей із порушеннями опорно-рухового апарату й олігофренією, що разом складають основну групу досліджуваних, і 184 батьків, які мають дітей без вад розвитку - ие контрольна група.

Вивчення емочійних переживань батьків проводилося за допомогою методик «Оиінка психічної активачії, інтересу, емоиійного тонусу, напруги й комфортності» (Н.А. Курганської, T.А. Немчин) $i$ «Семантичний диференціал» (Ч. Осгуда). Для виявлення статистичних відмінностей у кількісних значеннях досліджуваних шкал і понять був використаний критерій Манна-Уїнні, а для встановлення взаємозв'язку між показниками - кореляційний аналіз.

Батьки дітей, які не мають вад розвитку, частіше оцінюють свій стан більи бадьорим, а самопочуття - гарним на відміну від батьків дітей із комплексними порушеннями розвитку, які більше говорять про втому, погане самопочуття та підвищену напругу.

Коефіиієнти напруги в основній $і$ контрольній групах кількісно значно різняться лише у двох групах пережсивань («ставлення до хвороби» й «ставлення до лікування»). Можна виявити, щзо переживання батьків дітей із комплексними порушеннями розвитку відрізняються від переживань батьків контрольної групи за ступенем їх негативної забарвленості.

Проведене дослідження дозволяє зробити висновок про наявність тривалих негативно забарвлених переживань, у тому числі стану хронічної психічної напруженості, емочій страху й тривоги, і про перебування батьків дітей із комплексними порушеннями розвитку 6 умовах хронічного стресу. Емоційна фіксаиія на порушенні в розвитку дитини, неможливість перемкнутися на інші думки, емоції посилюють психічну напруженість.

Ключові слова: напруженість, емоційний тонус, тривога, діти з комплексними порушеннями розвитку, страх.

Постановка проблеми. Народження дитини 3 вадами розвитку є сильним травмуючим фактором для усієї сім'ї, який сприяє загалом зміні світосприйняття батьків. Зростає фізичне та психологічне навантаження на родину дитини, змінюючи тим самим взаємини у ній. Фактори, пов'язані із здоров'ям дитини не лише провокують емоційні переживання, але й впливають на особистісні особливості батьків. Ступінь важкості комплексного порушення розвитку дитини має суттєвий вплив на інтенсивність переживань батьків, рівень їх емоційної напруги та в цілому на їх суб' єктивне благополуччя. Порушення емоційного стану батьків сприяє неадекватному ставленню до вади дитини, що в майбутньому може призвести до її неправильного виховання та педагогічної занедбаності.

Аналіз останніх досліджень і публікацій. Починаючи із 60 -х років минулого століття, 3 'являються дослідження особливостей емоційних переживань батьками народження своєї дитини 3 порушеннями розвитку: E. Kubler-Ross, J. Blasher, M. Irvin, M. Klaus, L. Kennell, M. Семаго, Р. Майромян тощо. Простежуючи переживання батьками події, різні дослідники (Е. Kubler-Ross, J. Blasher, M. Irvin, M. Klaus, L. Kennell) дійшли висновку про закономірну зміну їхніх емоційних станів на шляху до адаптації: шок, заперечення, гнів, депресія [2, с. 157]. J. Blasher подає власну, дещо адаптовану щодо стадій E. Kubler-Ross, модель, яка перегукується з ідеями M. Irvin, M. Klaus i L. Kennell: шок, заперечення захворювання; усвідомлення реальності, яке супроводжується почуттями провини, смутку, відчаю, злості тощо; поступове примирення та прийняття реальності, реорганізація життя та реалістична адаптація до неповносправності [14, с. 55-68].

М. Семаго й Р. Майромян виділяють чотири фази реакцій батьків на народження дитини 3 
вадами розвитку: стресовий стан; негативізм, заперечення діагнозу; депресивний стан; стадія адекватних емоційних контактів, що означає початок соціально-психологічної адаптації членів сім'ї $[9$, с. 72$]$.

Сім'ї, які виховують дитину з комплексними порушеннями розвитку, стають безпорадними, їх становище характеризується як «внутрішній» (психологічний) i «зовнішній» (соціальний) глухий кут. Батьки перебувають у стресовій ситуації, яка спустошує як фізично, так і емоційно. Симптомами такого спустошення, як зазначать Н.Є. Карпова, Т.А. Стрелекалова, В.В. Ткачова, С.А. Хазова, проявляються на соматичному, психічному та поведінковому (соціальному) рівнях $[12$, c. $126 ; 11$, c. 210$]$.

В.В. Ткачова прийшла до висновку, що народження дитини з вадами, а потім ії подальше виховання, навчання, реабілітація і загалом спілкування $з$ нею $є$ тривалим патогенним фактором, що змінюе особистість батьків та їх життя в цілому. Окрім того, дослідниця виділяе кризові стани в родинах, які виховують дітей із фізичними відхиленнями: народження хворої дитини (до 3 років); період постановки іï діагнозу (3-5 років); період підтвердження попереднього діагнозу, підбір програми навчання (7-9 років); перший рік навчання в школі; перехід у старші класи; пубертатний період; період професійної орієнтації; розв'язання проблем особистого життя [11, с. 244].

R. Hill на основі ідей когнітивного підходу до терапії розробив теоретичну АBCX-модель сімейної кризи, відповідно до якої дитина 3 порушеннями розвитку розглядається в контексті моделі сімейного стресу як джерелопостійного стресового стану. Автор виділяе такі фактори, що можуть створювати психотравмуючу ситуацію: А-фактор - подія-стресор, що здатна змінити сімейну систему; В-фактор - сімейні ресурси, які допомагають протистояти стресу; С-фактор сприймання значущості стресової події для сім'ї; $\mathrm{X}$-фактор - криза, що виникає в результаті впливу на сім'ю факторів А, В, С, а це своєю чергою свідчить про нездатність сім'ї відновити баланс і стабільність [16, с. 17].

І.Б. Іванова виділяє суб' єктивні й чинники причин наявних проблем у сім'ях, які виховують дітей із вадами. Суб'єктивними здебільшого $є$ біологічний стан дитини, iіi хвороба, спадковість, здоров'я батьків, спосіб їх життя. Об'єктивних причин значно більше: медикосоціальні (пологова, післяпологова травма, низька кваліфікація медичного персоналу, наслідки катастрофи в Чорнобильській атомній електростанції, низький рівень медичного обслуговування), фінансові (складне матеріальне становище), світоглядні (суспільство не сприймає дітей із вадами своїми рівноправними членами), правові (недосконалість законодавства про охорону дитинства), інформаційні (відсутність інформації для батьків), професійні (зайнятість батьків, відсутність спеціалістів, які б займалися $з$ дитиною), освітні (низький рівень опіки держави фізичним і розумовим розвитком дітей з особливими потребами. Авторка після проведеного дослідження виявляє, що на першому місці - фінансові й матеріальні проблеми, на другому - психологічні (нервове перевантаження, нерозуміння, покинутість, самотність, моральні проблеми), на третьому - лікування та оздоровлення дитини [7, с. 62-65].

М.Н. Гуслова й Т.К. Стуре відзначають у батьків дітей із комплексними порушеннями розвитку ряд загальних особливостей особистості у вигляді сенситивності (підвищеної емоційної чуттєвості, вразливості), гіперсоціалізації (загостреного почуття відповідальності, складності компромісів) та захисної форми поведінки [4, с. 29].

О.В. Александрова й І.Б. Дерманова зауважують, що психоемоційне благополуччя батьків дітей із складними вадами розвитку, значно відрізняється за афективним, особистісним та когнітивним компонентом. Народження дитини з комплексними порушеннями розвитку активізує у батьків особистісні ресурси, сприяючи усвідомленню мети життя. Провідну роль тут відіграє активізація сімейних сенсів, спрямованих на підтримку або порятунок дитини, унаслідок зниженого прагнення до самореалізації. Для такої ситуації характерним є послаблення психічної активації, інтересу, емоційного тонусу, комфортності, наявність тривожності, зниження задоволеності життям в цілому [1, с. 38].

Т.Н. Висотина зазначає, що у батьків дітей 3 порушеннями розвитку загострюються тривожно-сензитивні риси особистості, астенодепресивні реакції у матерів і дисфоричні реакції у батьків таких дітей. Найбільший ступінь емоційно-особистісних порушень характерний для матерів. Окрім того, дослідниця виявила прямий взаємозв'язок між складністю емоційно-особистісних порушень у батьків (викривлення їх емоційної сфери) і структури комплексної вади у дитини [3, с.127].

I.M. Сфимова, провівши емпіричне дослідження зв'язку системного профіля мотивації 
батьків i ступеня їх батьківського вигорання, зауважує, що найбільший вплив на вигорання має вітальна та моральна мотивація. Ступінь вигорання тим вищий, чим нижче місце вітальної мотивації в профілі і чим вище місце моральної [5].

О.Ю. Кочерова, О.М. Филькина, Н.В. Долотова О.Н. Антишева й А.І. Малишкина визначають, що у батьків дітей з дитини 3 комплексними порушеннями розвитку часто зустрічаються такі емоційні порушення, як зосередженість на поганому самопочутті, тривожність, імпульсивність, гіпоманія [8, с. 8].

Постановка завдання. Метою статті є розгляд результатів емпіричного дослідження емоційних переживань батьків, які виховують дітей $з$ комплексними порушеннями розвитку.

Виклад основного матеріалу. У нашому емпіричному дослідженні взяло участь 152 батьків, які виховують дітей із складними мовленнєвими вадами та розумовою відсталістю, 136 батьків дітей із порушеннями опорно-рухового апарату та олігофренією, що разом складають основну групу досліджуваних і 184 батьків, які мають дітей без вад розвитку - це контрольна група.

Вивчення психічної напруженості батьків основної та контрольної груп проводилася за допомогою методик «Оцінка психічної активації, інтересу, емоційного тонусу, напруги та комфортності» (Н.А. Курганської, Т.А. Немчин) і «Семантичний диференціал» (Ч. Осгуда).

Згідно 3 першою методикою напруга - зосередження сил та уваги на чомусь, витрата великих зусиль та енергії; активація - стан організму, що характеризує рівень його збудження і реактивності; тонус - життєва активність, життєдіяльність; інтерес - стан, пов'язаний з інтересом до чого-небудь, прояв уваги.

Оцінка психічної активації, інтересу, емоційного тонусу, напруги та комфортності показала статистичні відмінності рівня психічної напруги в основній і контрольній групах. У таблиці 1 пред- ставлені статистичні відмінності за Критерієм Манна-Уїтні.

Дані таблиці свідчать, що існують статистично значущі відмінності в вибірках за характеристиками психічної активації, емоційного тонусу, напруги і комфортності. Характеристики параметрів «психічна активація», «емоційний тонус» i «комфортність» нижче в контрольній групі. Отже, батьки здорових дітей частіше оцінюють свій стан як бадьорий, радісний, мають гарне самопочуття, настрій та бажання працювати. Батьки дітей 3 комплексними порушеннями розвитку більше говорять про втому, бажання відпочити, млявість, заклопотаність, про поганий настрій і самопочуття. Статистичні дані по параметру «напруга», навпаки, вище в основний вибірці. Таку шкалу ми вважаємо найбільш значущою під час вимірювання хронічного стресу. Можна говорити про те, що батьки, які виховують дітей з вадами, в порівнянні з батьками здорових дітей, частіше перебувають у стані психічної напруги.

За параметром «інтерес» не існує статистично значущих відмінностей в основній і контрольній вибірках.

Оцінка психічного напруження в вибірках проводилася і за допомогою методики «Семантичний диференціал». Застосовуваний варіант методики складено Л.М. Шипіциною, у якій вона вказує на те, що методика Ч. Осгуда, адаптована нею, вимірює рівень емоційної напруженості.

Досліджуваним пропонується оцінити поняття «Мій син / дочка», «Майбутнє моєї дитини», «Хвороба мого сина/дочки», «Я сам» за факторами «оцінка», «сила» i «активність». Кожна шкала представлена чотирма парами антонімічних прикметників. Для виявлення статистичних відмінностей у кількісних значеннях досліджуваних шкал і понять був використаний критерій Манна-Уїтні. В таблиці 2 наведені значення відмінностей в шкалах СД для основної та контрольної вибірок.

Таблиця 1

Значення відмінностей показників за опитувальником «Оцінка психічної активації, інтересу, емоційного тонусу, напруги і комфортності» в групах батьків дітей 3 комплексними порушеннями розвитку і батьків здорових дітей

\begin{tabular}{|c|c|c|c|}
\hline Параметри & $\begin{array}{c}\text { Батьки дітей } \\
\text { з комплексними } \\
\text { порушеннями розвитку }\end{array}$ & $\begin{array}{c}\text { Батьки дітей } \\
\text { без вад розвитку }\end{array}$ & Достовірна розбіжність \\
\hline Психічна активація & 9,6 & 1,95 & $\mathrm{p} \leq 0,01$ \\
\hline Інтерес & 1,15 & 0,68 & - \\
\hline Емоційний тонус & 7,65 & 3,34 & $\mathrm{p} \leq 0,01$ \\
\hline Напруга & 7,57 & 3,39 & $\mathrm{p} \leq 0,01$ \\
\hline Комфортність & 4,68 & 5,38 & $\mathrm{p} \leq 0,01$ \\
\hline
\end{tabular}


Значення відмінностей показників по критерію Манна-Уїтні в основній і контрольній групах за методикою «Семантичний диференціал»

\begin{tabular}{|c|c|c|c|}
\hline \multirow{3}{*}{ Шкали } & \multicolumn{2}{|c|}{ Середнс значення } & \multirow[b]{2}{*}{ Рівень достовірності } \\
\hline & Основна група & Контрольна група & \\
\hline & \multicolumn{3}{|c|}{ Фактор «Оцінка» } \\
\hline Моя дитина & 11,55 & 15,14 & $p \leq 0,01$ \\
\hline Майбутнє моєї дитини & 7,91 & 3,18 & $p \leq 0,01$ \\
\hline Хвороба моєї дитини & 7,12 & 3,71 & $p \leq 0,01$ \\
\hline Я сам (a) & 9,86 & 13,72 & $p<0,01$ \\
\hline \multicolumn{4}{|c|}{ Фактор «Сила» } \\
\hline Моя дитина & 0,83 & 7,59 & $\mathrm{p} \leq 0,01$ \\
\hline Майбутнє моєї дитини & 1,16 & 0,59 & \\
\hline Хвороба моєї дитини & 8,91 & 2,21 & $\mathrm{p} \leq 0,01$ \\
\hline Я сам (a) & 6,48 & 8,47 & $\mathrm{p}<0,01$ \\
\hline \multicolumn{4}{|c|}{ Фактор «Активність» } \\
\hline Моя дитина & 5,35 & 12,88 & $\mathrm{p} \leq 0,01$ \\
\hline Майбутнє моєї дитини & 9,11 & 2,41 & $\mathrm{p} \leq 0,01$ \\
\hline Хвороба моєї дитини & 1,02 & 1,67 & - \\
\hline Я сам (a) & 7,51 & 11,55 & $\mathrm{p}<0,01$ \\
\hline
\end{tabular}

Аналіз таблиці дозволяє зробити висновок про те, що значення за фактором «активність» поняття «моя дитина» нижче в основній вибірці (тобто батьки дітей з вадами розвитку оцінюють свою дитину як менш активну, ніж батьки здорових дітей (значущість відмінностей $\mathrm{p}<0,01$ ). Числові показники за факторами «оцінка» та «активність» поняття «майбутнє моєї дитини» також нижче у батьків, які виховують дітей з комплексними порушеннями розвитку: батьки основної вибірки оцінюють майбутнє своєї дитини як менш активне і менш значне, ніж батьки контрольної групи (значущість відмінностей $\mathrm{p}<0,01)$. Найбільші статистичні відмінності за критерієм Манна-Уїтні спостерігаються за фактором «оцінки» в понятті «хвороба моєї дитини» (значущість відмінностей $\mathrm{p}<0.001)$. Батьки основної вибірки оцінюють вади своїх дітей за шкалами «сила» i «оцінка» як значно складніші, ніж батьки здорових дітей. У той же час значення за шкалою «активність» не мають статистично значущих відмінностей в вибірках. Тут, швидше за все, можна говорити про те, що для батьків не має значення, як протікає захворювання - гостро або хронічно, зі зміною стабільності стану або без нього, а має значення сам факт наявності хвороби чи певної вади розвитку у дитини.

В основній групі за поняттям «я сам(а)» отримані нижчі показники $(9,86)$ за фактором «оцінка». Тобто у батьків дітей з комплексними порушеннями розвитку значно страждає оцінка свого «Я». Одночасно з цим статистичні відмінності за факторами «сила» $\mathrm{i}$ «активність» також виявлені.
Був проведений кореляційний аналіз даних основної вибірки за шкалами «Семантичного диференціала» для виявлення прямої та зворотньої залежності. Пряма кореляційна залежність виявлена між: фактором «активність» поняття «майбутнє моєї дитини» і шкалою «активність» поняття «моя дитина» (чим активнішою та рухливою $є$ дитина, на думку батьків, тим активніше іiі майбутне); між факторами «активність» та «оцінка» поняття «майбутне моєї дитини» (чим активніша дитина, тим «якісніше» життя буде у неї); між факторами «оцінка» понять «я сам» $\mathrm{i}$ «майбутнє моєї дитини» (чим вище самооцінка батьків, тим краще ними оцінюється майбутнє дитини, і навпаки; між факторами «оцінка» понять «я сам» і «хвороба моєї дитини» (тобто чим вище самооцінка батьків, тим хвороба дитини оцінюється як «легша»). Зворотній кореляційний зв'язок за шкалами СД в основний вибірці виявлено між: факторам «сила» поняття «хвороба моєї дитини» і фактором «оцінка» поняття «майбутнє моєї дитини» (на думку батьків дітей 3 комплексними вадами розвитку, чим «сильніше» порушення дитини, тим важче буде іï майбутнє); між фактором «сила» поняття «хвороба моєї дитини» $\mathrm{i}$ «активність» поняття «майбутнє моєї дитини» (як вважають батьки основної групи, чим «сильніше» хвороба дитини, тим менш активним буде ії майбутнє).

Стан психічної напруженості i емоційного переживання діагностувалися також за допомогою методики «Незакінчені речення». У таблиці 3 представлено статистичні показники та коефіцієнт емоційної напруги в основній і контрольній групах. 
Показники емоційної напруги в основній і контрольній групах за шкалами методики «Незакінчені речення»

\begin{tabular}{|c|c|c|c|c|c|c|}
\hline \multirow{2}{*}{ Група речень } & \multicolumn{3}{|c|}{ Основна група } & \multicolumn{3}{|c|}{ Контрольна група } \\
\cline { 2 - 8 } & $\mathbf{M}$ & $\mathbf{M a x}$ & К напруги & М & Мах & К напруги \\
\hline Уявлення про здоров'я & 2 & 3 & 0,66 & 1,82 & 2,5 & 0,72 \\
\hline Уявлення про хворобу & 2,83 & 4 & 0,70 & 2,04 & 3 & 0,68 \\
\hline Ставлення до хвороби & 3,36 & 4 & 0,84 & 2,75 & 4 & 0,68 \\
\hline Ставлення до лікування & 1,78 & 4 & 0,44 & 1,65 & 2,5 & 0,66 \\
\hline Уявлення про майбутнє & 0,97 & 2 & 0,48 & 0,7 & 1,5 & 0,46 \\
\hline Ставлення родини до хвороби & 2,19 & 2 & 0,62 & 1,85 & 3 & 0,61 \\
\hline Ставлення дитини до лікарів & 1,59 & 3 & 0,53 & 1,3 & 2,5 & 0,52 \\
\hline
\end{tabular}

Найбільші коефіцієнти емоційної напруги, як в основний, так і контрольної вибірках, отримані в групах речень «ставлення до хвороби» $(0,84 \mathrm{i}$ 0,68 відповідно), «уявлення про хворобу» $(0,70$ і 0,68$)$ і «уявлення про здоров'я» $(0,66$ і 0,72$)$. Коефіцієнт напруги в групі речень «ставлення до лікування» вище середнього в контрольній групі $(0,66)$, і середній - в основний $(0,44)$. Фактично мало відрізняються коефіцієнти напруги в основній і контрольній вибірках по групах речень «уявлення про хворобу» (0,70 і 0,68 відповідно), «уявлення про майбутнє» $(0,48$ і 0,46$)$, «ставлення сім'ї до хвороби» $(0,62$ і 0,61$)$, «ставлення дитини до лікарів» $(0,53$ і 0,52$)$.

Таким чином, аналіз речень дозволяє зробити висновок, що незважаючи на те, коефіцієнти напруги в основній і контрольній групах у представленій методиці кількісно значно різняться лише в двох групах переживань («ставлення до хвороби» і «ставлення до лікування»), за допомогою якісного аналізу можна виявити, що переживання батьків дітей-інвалідів відрізняються від переживань батьків контрольної групи за ступенем їх негативної забарвленості.

Найбільш змістовно i повно незакінчені речення продовжували батьки основної групи. Батьки контрольної групи, виконуючи таку методику, демонструючи здивування з приводу змісту незакінчених речень, оскільки їм не пояснювалися, що вони беруть участь в дослідженні як контрольна група, i їх відповіді будуть порівнюватися з відповідями батьків, які виховують дітей 3 вадами розвитку.

Якісний аналіз отриманих речень дозволив зробити висновки, що батьки дітей 3 комплексними порушеннями розвитку формують свою концепцію захворювання дитини. Найчастіше вона представлена таким чином: «Існують винні в захворюванні дитини, вона має ваду через чиюсь недбалість». Найчастіше винними в хворобі виявляються лікарі - 24,9\% відповідей, 15,7\% батьків винними вважають себе, 33,3\% батьків називають об'єктивну причину порушення у розвитку дитини (процес протікання вагітності і пологів або якусь іншу «медичну причину»).

Доповнюючи незакінчені речення, батьки дітей 3 вадами вказують на переживання своїх почуттів частіше, ніж батьки контрольної групи, говорячи про переживання болю, тяжкості, почуття провини, почуття страху. Невеликий відсоток батьків основної групи все ж сподівається на одужання своєї дитини - 13,5\%. Батьки основної групи усвідомлюють, що для виховання хворої дитини необхідно дуже багато сил $(10,2 \%)$, часу і уваги до дитини $(15,3 \%)$, засобів $(33,3 \%)$, терпіння (25,6\%). Абсолютна більшість $(97,5 \%)$ батьків основної групи мріють щоб їх дитина одужала. Хоча деякі батьки усвідомлюють нереалізованість своїх бажань, об'єктивно оцінюючи стан своєї дитини («Я хочу, що б коли-небудь моя дитина що-небудь навчився робити сама»).

Багато батьків (45\%) основної групи беруть на себе відповідальність за стан своєї дитини на сьогоднішній день, 22,5\% - на лікарів і процес лікування, а по 12,5\% сподіваються на Бога та саму дитину. Для порівняння батьки контрольної групи в 85\% випадках говорять про те, що «ії здоров'я залежить, перш за все, від неї самої».

Закінчуючи речення «найнеприємніше в хворобі дитини...», батьки основної групи найчастіше вказують на якусь конкретну дисфункцію дитини. Водночас можна зробити висновок, що найбільшу значущість для батьків має розвиток рухових навичок - 45\% відповідей, $34,5 \%$ уза- 
гальнюють стан дитини, позначаючи його як «безпорадність», 20,5\% батьків близькі до усвідомлення того, що захворювання їхньої дитини невиліковне.

Відповіді батьків основної групи щодо майбутнього ми умовно розділили на чотири підгрупи. Перша, найбільша підгрупа батьків $(48,6 \%)$ уявляє собі «позитивний образ майбутнього», друга підгрупа $(8,1 \%)$ представляє «негативний образ майбутнього», деякі батьки погано уявляють (24,3\%) або взагалі не уявляють собі майбутнього $(8,1 \%)$.

Занижена самооцінка батьків основної групи простежується в реченні «Мої близькі думають, що я ...». У багатьох дослідженнях, присвячених вивченню особистості батьків дітей із комплексними порушеннями розвитку, в тому числі й у нашому, відзначається, що самооцінка батьків таких дітей нижче, ніж у батьків, які виховують здорових дітей. Це стає зрозумілим і під час аналізу методики «Незакінчені речення» - 27,7\% батьків низько оцінюють свою діяльність. Серед відповідей $є$ позитивна оцінка себе й своїх дій (41,6\%). Серед відповідей батьків основної групи нами виділені відповіді, де батьки або не хочуть (або не можуть) вербалізувати свої думки. Звертає на себе увагу такий факт, що лише двічі у батьків дітей з комплексними порушеннями розвитку прозвучала тема відмови від дитини 3 низьким реабілітаційним потенціалом («Мої близькі думають, що я права, що з ним займаюся, що не відмовилася»).

Цікаві результати отримані в реченні «Якби всі знали, як я боюся ...». У цій реченні були виділені три основні теми, а саме: смерть дитини $-17,1 \%$ відповідей; продовження хвороби на все життя $42,8 \%$ і боязнь майбутнього - $17,1 \%$ відповідей.

Нами виділено групу відповідей, яку ми назвали «вам не зрозуміти» («Якби всі знали, як я боюся ... Я не хочу, щоб це хтось знав», «Коли я вперше дізнався про хворобу дитини ... Вам це не пояснити»). Таким чином, виховання в сім’і дитини $з$ вадами розвитку сприймається батьками як виняткове та неповторне явище, тому вони переконані, що іншим не зрозуміти їх переживань. Хочеться підкреслити, що цілий ряд дослідників вважає цю особливість свідомості особистості, яка пережила будь-який вид психічної травми, коли все, що відбувається 3 людиною сприймається ним як виняткове явище, що сталося тільки з нею. Про це ж у своїй теорії про психічну травму говорить і Дж. Ялом. На думку людей, які пережили психічну травму, їх переживання, досвід настільки унікальні, що іншим людям їх зрозу- міти неможливо. Інші люди починають здаватися нецікавими, нічого не розуміючими в життя. Це переконання Дж. Ялом називає базисне уявлення про ізоляцію [6].

У всіх матеріалах методики «Незакінчені речення» простежується наявність явного або приховуваного почуття провини перед дитиною. Особливо чітко це простежується у реченні «3 хворобою моєї дитини у мене пов'язано почуття ...». 22,2\% батьків основної групи говорять в цьому реченні про пережите почутті провини, такий же відсоток батьків (22,2\%) говорять про переживання ними почуття страху. Аналіз цього речення дозволяє зробити висновок про те, що абсолютна більшість батьків основної групи переживають лише негативні емоції, пов'язані i3 захворюванням дитини. Переживання батьків 3 контрольної групи в такому реченні також негативно забарвлені, але відмінності видно в семантичній насиченості речень («3 хворобою моєї дитини у мене пов'язано почуття болю» 8,3\%, «... ненависті» - 13,8\%, «... тривоги» - 8,3\%, «... невпевненості», «... жалю» - по 5,5\% відповідей у основний вибірці). Батьки дітей із комплексними порушеннями розвитку вживають інші семантично насичені слова порівняно з батьками контрольної групи («3 хворобою моєї дитини у мене пов'язано почуття незадоволеності та тяжкості в життя», «... відчаю», «... розгубленості, тривоги», « ... гіркоти, як ніби в житті я зробила щось не так », «... паніки» тощо.

За результатами методики «Незавершені речення» спостерігається існування симбіотичного зв'язку батьків з дитиною. Дитина 3 комплексними порушеннями розвитку та іiі захворювання являють певну діаду, в яку включені батьки, найчастіше мати або бабуся. Подібна структура життєвої ситуації характерна і для здорової дитини в ранньому віці, але в міру дорослішання відбувається процес «вивільнення» від батьків. Батьки дітей з вадами, самі того не усвідомлюючи, розглядають своє життя та життя своєї дитини як єдину систему («У моїй родині все життя підлаштовано під дитину»). Особливо явно цей зв' язок простежується у реченнях, де батьки, говорячи про дитину, вживають займенник «ми» («Я вірю, що в майбутньому ми почнемо ходити», «... у нас все буде добре», «Якби всі знали, як я боюся, щоб у нас більше нічого не знайшли»).

За результатами «Незакінчених речень» у батьків, які виховують дітей 3 комплексними порушеннями розвитку, виявляється наявність тривоги та страху. Особливо часто батьки дітей з вадами 
розвитку говорять про переживання ними почуття страху: «Коли я думаю про ії хвороби, я боюся за неї», «... мені стає страшно», «коли стало відомо про хворобу моєї дитини мені стало дуже страшно», «... страшно і погано». Переживання почуття тривоги простежується в таких реченнях як: «Коли я думаю про ваду дитини, то дуже сильно переживаю», «... мені дуже важко, часом не знаю, що мені робити», «коли ми з дитиною приходимо до лікаря я чомусь очікую чогось поганого».

Висновки. Таким чином, за даними методики «Незакінчені речення можна зробити такі висновки: на певному етапі хвороби дитини батьки дітей 3 комплексними порушеннями розвитку формують свою концепцію захворювання дитини. Відповідно до цієї теорії батьки визначають своє ставлення та поведінку щодо дитини, до сім'ї, лікарям та інших людей, а також до себе; батьки виділяють зовнішні, внутрішні та незалежні причини того, що сталося в їхній родині. 3 перебігом хвороби зовнішня причина поступово змінюється на внутрішню; цю закономірність відзначають такі психологи як Н. Heckhause [15] та G. Krampen [17]; батьки дітей з порушеннями розвитку сприймають свою життєву ситуацію як виняткову за своїм характером; переживання батьків 3 приводу вади їхньої дитини відрізняються негативним емоційним забарвленням і глибшим негативним семантичним навантаженням на них. Часто батьки одночасно переживають кілька негативних емоцій (сором, провину, горе), що впливає на особистість батьків і їх поведінку; почуття глибокої прихиль- ності до дитини поєднується з почуттям провини перед нею, яке згодом призводить до зниження самооцінки батьків; переживання почуття страху та тривоги, що належать до тривожного ряду, підтверджують теорію про проживання батьків, які виховують дитину 3 низьким реабілітаційним потенціалом, в умовах хронічного стресу; дитина 3 комплексними порушеннями розвитку та іiі батьки (найчастіше це мати або бабуся) утворюють міцний симбіотичний зв'язок один з одним.

У цілому, проведене дослідження дозволяе зробити висновок про наявність тривалих негативно забарвлених переживань, у тому числі стану хронічної психічної напруженості, емоцій страху та тривоги, i, отже, про перебування батьків дітей з комплексними порушеннями розвитку в умовах хронічного стресу. Це тим вірніше, що вік дітей, батьки яких. брали участь в дослідженні старше двох років, а часовий показник хронічного стресу, на думку дослідників (Н.В. Тарабрина, Н.Є. Харламенкова, Ю.В. Биховец, Л.Ш. Мустафина, О.А. Ворона, Н.Н Казимова, О.Н. Димова, Н.С. Шаталова) повинен бути не менше ніж 6 місяців. Емоційна фіксація на порушенні у розвитку дитини, неможливість перемкнутися на інші думки, емоції посилюють психічну напруженість.

Перспектива подальших досліджень полягає у вивченні впливу сукупності негативних емоційних переживань і психічної напруги на зміну ціннісносмисловий складової частини образу світу батьків дітей 3 комплексними порушеннями розвитку, зокрема на трансформацію їх базисних переконань.

\section{Список літератури:}

1. Александрова О.В., Дерманова И.Б. Психоэмлциональное благополучие матерей детей с тяжелыми и неизлечимыми заболеваниями. Медицина: теория и практика. 2019. Том 4. С. 37-38.

2. Андрейко Б.В. Соціальні проблеми, що детермінують стани батьків дитини з порушеннями розвитку. Науковий вісник Херсонського державного університету. 2015. Випуск 1. Том 2. С. 156-160.

3. Высотина Т.Н. Личностные особенности родителей, воспитывающих детей со сложными нарушениями психического развития. Вестник СПбГУ. 2011. Серия 12. Вып. 2. С. 122-127.

4. Гуслова М.Н., Стуре Т.К. Психологическое изучение матерей, воспитывающих детей-инвалидов. Дефектология. 2003. № 6. С. 28-31.

5. Ефимова И.Н. Роль системного профиля мотивации в развитии родительского выгорания. Системная психология и сочиология. 2014. № 9. С. 23-32.

6. Заборина Л.Г. Базисные убеждения и смыслы родителей детей с ограниченными возможностями здоровья : монография / Забайкал. гос. ун-т. Чита : Изд-во ЗабГГПУ, 2012. 180 с.

7. Іванова І.Б. Соціально-психологічні проблеми дітей-інвалідів. Київ : Логос, 2000. 87 с.

8. Кочерова О.Ю., Филькина О.М., Долотова Н.В., Малышкина А.И., Антышева Е.Н. Психологические особенности матерей, воспитывающих детей инвалидов. Вестник РАMН. 2014. № 5-6. С. 92-102.

9. Семаго М.М. Основные аспекты психологического подхода при консультировании семей с детьми, имеющими отклонение в развитии. Клинико-генетическое и психолого-педагогическое изучение и коррекиия аномалий психического развития у детей : сборни к научных трудов. Москва, 1991. С. 130.

10. Тарабрина Н.В., Харламенкова Н.Е., Быховец Ю.В., Мустафина Л.Ш., Ворона О.А., Казымова Н.Н., Дымова Е.Н., Шаталова Н.Е. Посттравматический стресс и картина травматических событий в разные периоды взрослости. Психологический журнал. 2016. Т. 37. № 6. С. 82-96. 
11. Ткачева В.В. Технологии психологической помощи семьям детей с отклонениями в развитии. Москва : АСТ : Апрель, 2007. 320 с.

12. Хазарова С.А. Ментальные ресурсы субъекта и жизнеспособность личности. Жизнеспособность человека: индивидуальные, профессиональные и соииальные аспекты / Ред. А.В. Махнач, Л.Г. Дикая. Москва : Изд-во Институт психологии РАН, 2016. С. 210-219.

13. Шебанец Е.Ю., Хатит Ф.Р. Ребенок-инвалид как отягчающий фактор положения женщины-матери в семье: психолого-педагогический аспект. Вестник АГУ. 2015. Выпуск 4 (169). С. 125-129.

14. Blasher J. Sequential stages of parental adjustment to the birth of a child with handicaps : fact or artifact? Mental retardation. 1984. Vol. 22. P. 55-68.

15. Heckhausen H. Entwicklungsshritte in der Kausalattribution von Handlungsergebnissen. Kindliche Erklarungsmuster. Weinheim : Beltz, 1983. S. 49-85.

16. Hill R. Families under stress. New York : Harper and Row, 1946. 443 p.

17. Krampen G. Fragebogen zu Kompetenz- und Kontrollüberzeugungen. Göttingen : Hogrefe, 1991. 127 S.

18. Kubler-Ross E. On death and dying. New York : Macmillan, 1969. 304 p.

\section{Shevchuk V.V. EMOTIONAL EXPERIENCES OF PARENTS OF CHILDREN WITH COMPLEX DEVELOPMENTAL DISORDERS}

The article presents the results of theoretical and empirical research of psychological features of emotional experiences of parents who raise children with complex developmental disorders in comparison with parents of children without developmental disabilities.

Our empirical study involved 152 parents raising children with speech and mental retardation, 136 parents of children with musculoskeletal disorders and oligophrenia, who together make up the main group of subjects and 184 parents who have children with disabilities - this control group.

The study of parents' emotional experiences was carried out using the methods: "Assessment of mental activation, interest, emotional tone, tension and comfort" (N.A. Kurganskaya, T.A. Nemchin) and "Semantic Differential" (Ch. Osgood). The Mann-Whitney test was used to identify statistical differences in the quantitative values of the studied scales and concepts, and correlation analysis was used to establish the relationship between the indicators.

Parents of children who do not have developmental disabilities are more likely to assess their condition as more energetic and well-being, in contrast to parents of children with complex developmental disorders, who talk more about fatigue, malaise and increased stress.

Stress coefficients in the main and control groups differ significantly quantitatively in only two groups of experiences ("attitude to the disease" and "attitude to treatment"), we can find that the experiences of parents of children with complex developmental disorders differ from the experiences of parents in the control group. color.

The study concludes that there are long-term negative experiences, including a state of chronic mental tension, emotions of fear and anxiety, and the presence of parents of children with complex developmental disorders in chronic stress. Emotional fixation on the violation of the child's development, the inability to switch to other thoughts, emotions increase mental tension.

Key words: tension, emotional tone, anxiety, children with complex developmental disorders, fear. 